Available online on 15.07.2018 at http://jddtonline.info
Journal Of Drug Delivery and Therapeutics
$\begin{gathered}\text { Open Access to Pharmaceutical and Medical Research } \\ \text { 2011-18, publisher and licensee JDDT, This is an Open Access article which permits unrestricted non- } \\ \text { commercial use, provided the original work is properly cited }\end{gathered}$

Open $\odot$ Access

Research Article

\title{
COMPARATIVE QUALITATIVE AND QUANTITATIVE PHYTOCHEMICAL ANALYSIS OF CALOTROPIS GIGANTEA AND CALOTROPIS PROCERA ROOTS
}

\author{
Pratibha Mishra*, Khushwant S. Yadav, Girendra Gautam \\ Institute of Pharmaceutical Sciences and Research Centre, Bhagwant University, Ajmer, Rajasthan
}

\section{ABSTRACT}

Phytochemicals are secondary metabolites produced by all plants in which some has medicinal uses. The comparative Qualitative and Quantitative phytochemical analysis of root extracts in aqueous, Chloroform, Ethyl acetate and ethanol extracts of Calotropis gigantea and calotropis procera Linn. were investigated. The comparative phytochemical analysis revealed the presence of alkaloids, saponins, tannins, flavonoids, terpenoids, glycosides, phenols group in varying concentrations. The comparative studies result of the above two plants gives a basis of its use in traditional medicine to manage ailments and disorders. It also contains some biologically active constituents worthy of further investigations.

Keywords: Comparative, Qualitative, Quantitative, phytochemical, Calotropis gigantea and calotropis procera

Article Info: Received 26 March, 2018; Review Completed 28 June 2018; Accepted 09 July 2018; Available online 15 July 2018

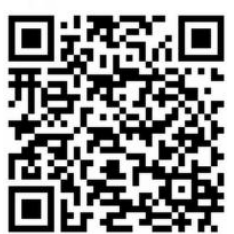

Cite this article as:

Mishra P, Yadav KS, Gautam G, Comparative qualitative and quantitative phytochemical analysis of Calotropis gigantea and Calotropis procera roots, Journal of Drug Delivery and Therapeutics. 2018; 8(4):179-184 DOI: http://dx.doi.org/10.22270/jddt.v8i4.1757

Pratibha Mishra, Institute of Pharmaceutical Sciences and Research Centre, Bhagwant University, Ajmer, Rajasthan

\section{INTRODUCTION}

Medicinal plants are used to maintain and promote healthy life, prevent disease and cure ailments. The World Health Organization supports the use traditional medicine provided they are proven to be efficacious and safe. Nearly $80 \%$ of the world's population relies on traditional medicines for primary health care, mast of which involve the use of plant extracts. In India almost 95\% of the prescriptions were used in Unani, Ayurveda, Homeopathy and Siddha. ${ }^{1}$

Phytochemicals are primary and secondary metabolites, which are naturally occurring in the leaves, vegetables, and roots that have defense mechanism and protect from various diseases. Primary metabolites are proteins, carbohydrates, chlorophyll, lipids and common sugars, which are synthesized during photosynthesis, and these organic compounds are essential for plant life and growth and development. Secondary metabolites are tannins, flavonoids, phenolics, saponins and alkaloids, which are synthesized by the plant during development and are time, tissue and organ specific. ${ }^{2,3}$

The medicinal value of these plants lies in some chemical substances that produce a definite physiological action on the human body. The most important property of these bioactive constituents of plants is that they are more effective with little or no side effects when compared to the commonly used synthetic chemotherapeutic agents. Qualitative phytochemical screening will help to understand a variety of chemical compounds produced by plants and quantification of those metabolites will help to extract, purify and identify the bioactive compounds for useful aspects to human beings. 1,3

In this research work comparative Qualitative and Quantitative phytochemical analysis of root extracts in aqueous, Chloroform, Ethyl acetate and ethanol extracts of indigenous medicinally important plants of Calotropis gigantea and calotropis procera Linn. were investigated. ${ }^{1,2}$ 


\section{MATERIALS AND METHODS}

\section{Collection of Plant Material}

The roots of Calotropis gigantea and calotropis procera Linn. was collected from in and around Bhopal city, Madhya pradesh. The collected plant materials were washed thoroughly with water separately, dried under shade at room temperature

\section{Authentication of Plant Material}

It was authenticated by Dr. Zia ul Hassan, HOD, Dept. of Botany, Saifia Science College, Bhopal. A voucher specimen was submitted and preserved in the Department of Pharmacy, Bhagwant University, Ajmer.

\section{Extract preparation}

\section{Extraction procedure ${ }^{3,4}$}

Following procedure was adopted for the preparation of extracts from the shade dried and powdered herbs:

\section{Defatting of Plant Material}

Powdered plant material (roots) of Calotropis gigantea and Calotropis procera were extraction with petroleum ether using maceration process. The extraction was continued till the defatting of the material had taken place.

\section{Extraction by hot continuous percolation process}

50g. of Calotropis gigantea and Calotropis procera dried plant material (roots) were exhaustively extracted with chloroform, ethyl acetate, ethanol and water. The extracts were evaporated above their boiling points. Finally the percentage yields were calculated of the dried extracts.

\section{Determination of Percentage yield}

\section{Calculation of percentage yield}

The percentage yield of yield of each extract was calculated by using formula:

$$
\text { Percentage yield }=\frac{\text { Weight of extract }}{\text { Weight of powdered drug taken }} \times 100
$$

\section{Qualitative phytochemical analysis ${ }^{5-9}$}

The extracts obtained by solvent extraction were subjected to various qualitative tests to detect the presence of plant constituents.

\section{Preparation of Test Solution}

The test solution was prepared by taking $1 \mathrm{~g}$ of the extract in $25 \mathrm{ml}$ of water.

\section{A. Test for Carbohydrates}

Following tests were carried out for carbohydrates.

a) Molisch's test: In a test tube containing extract of drug, added two drop of freshly prepared $20 \%$ alcoholic solution of $\alpha$ - napthol and mixed concentrated sulphuric acid along the sides of the test tube. If carbohydrate present purple color or reddish violet color produce at the junction between two liquids. b) Benedict's test: In a test tube containing extract of drug add benedict's solution, mix well, boiled the mixture vigorously for two minutes and then cooled. Formation of red precipitate due to presence of carbohydrates.

c) Barfoed's test: The barfoed's solution added to 0.5 $\mathrm{ml}$ of solution under examination, heated to boil. Formation of red precipitate of copper oxide was indicated the presence of carbohydrates.

d) Anthrone test: To the two $\mathrm{ml}$ of anthrone test solution, add the extract of drug. A green or blue colour indicated the presence of carbohydrate.

\section{B. Test for Alkaloids}

a) Dragendorff's Test: Few mg of extract of the drug dissolved in $5 \mathrm{ml}$ of water added $2 \mathrm{M}$ hydrochloric acid until an acid reaction occurred; $1 \mathrm{ml}$ of dragendorff's reagent (potassium bismuth iodide solution) was added an orange red precipitate indicated the presence of alkaloids.

b) Wagner's test: Acidify the extract of drug with 1.5 $\%$ v/v of hydrochloric acid and added a few drop of Wagner's reagent (iodine potassium iodide solution). Formations of reddish brown precipitate indicated the presence of alkaloids.

c) Mayer's Test: Two $\mathrm{ml}$ of extract solution was treated with 2 - 3 drops of Mayer's reagent was added (potassium mercuric iodide solution) formation of dull white precipitate indicated the presence of alkaloid.

d) Hager's Test: Extract of the drug solution was treated with $3 \mathrm{ml}$ of Hager's reagent (saturated solution of picric acid) formation of yellow precipitate confirmed the presence of alkaloids.

\section{Test for Glycosides}

a) Legal's test: Extract solution dissolved in pyridine then sodium nitroprusside solution was added to it and made alkaline. Pink red colour indicated the presence of glycosides.

b) Baljet's test: To the drug extract, sodium picrate solution was added, yellow to orange colour was indicated the presence of glycosides.

c) Borntrager's test: Few $\mathrm{ml}$ of dilute sulphuric acid solution, the test solution of extract was added. It was filtered and the filtrate was boiled with ether or chloroform. Then organic layer was separated to which ammonia was added, pink, red or violet colour was produced in orange layer confirmed the presence of glycosides.

d) Keller Kiliani test: Methanolic extract was dissolved in glacial acetic acid containing trace of ferric chloride one $\mathrm{ml}$ concentrated sulphuric acid was added carefully by the side of the test tube. A blue colour in the acetic acid layer and red colour at the junction of the two liquid indicated the presence of glycosides. 


\section{Test of Saponins}

a) $1 \mathrm{ml}$ of alcoholic extract was diluted with $20 \mathrm{ml}$ distilled water and shaken in graduated cylinder for 15 minutes. One $\mathrm{cm}$ layer of foam indicated the presence of saponins.

\section{E. Test for Flavanoids}

a) Shinoda test: In the test tube containing alcoholic extract of the drug added 5 - 10 drops of dil. hydrochloric acid followed by the small piece of magnesium. In presence of flavonoids a pink, reddish pink or brown color was produced.

\section{F. Test for Protein and Amino acid}

a) Biuret's test: To 2 - $3 \mathrm{ml}$ of the extract of drug added in $1 \mathrm{ml}$ of $40 \%$ sodium hydroxide solutions and 2 drops of $1 \%$ copper sulphate solution mix thoroughly, a purplish - violet or pinkish - violet colour produced that indicates the presence of proteins.

b) Ninhydrin's test: Two drops of freshly prepared 0.2 $\%$ ninhydrin reagent was added to the extract and heated to boiling for 1 - 2 min. and allow cooling. A blue colour developed that indicating the presence of proteins, peptides or amino acids.

c) Xanthoprotein test: To the extract in a test tube, add conc. nitric acid. A white precipitate was obtained and upon heating turns to yellow and cool the solution carefully. Added $20 \%$ of sodium hydroxide solution in excess orange colour indicated presence of aromatic amino acid.

d) Millon's test: The small quantity of extract of the drug dissolved in distilled water added 5 - 6 drop of millon's reagent. A white precipitate was formed which turned red on heating, indicated the presence of proteins.

e) Lead Acetate test: The extract was taken and two ml of $40 \%$ sodium hydroxide solution was added and boiled, glacial acetic acid was added and cooled than added $1 \mathrm{ml}$ of lead acetate solution, gray black precipitate was formed which indicated presence of sulphur containing amino acid.

\section{G. Detection of phenols}

Ferric Chloride Test: Extracts were treated with 3-4 drops of ferric chloride solution. Formation of bluish black colour indicates the presence of phenols

Quantitative phytochemical analysis ${ }^{10-13}$

Estimation of total Phenolic and flavanoid Content

Total Phenolic content estimation

Principle: The total phenolic content of the extract was determined by the modified Folin-Ciocalteu method.

Preparation of Standard: $10 \mathrm{mg}$ Gallic acid was dissolved in $10 \mathrm{ml}$ methanol, various aliquots of 5$25 \mu \mathrm{g} / \mathrm{ml}$ was prepared in methanol.

Preparation of Extract: $10 \mathrm{mg}$ of dried extracted dissolve in $10 \mathrm{ml}$ methanol and filter. Two $\mathrm{ml}(1 \mathrm{mg} / \mathrm{ml})$ of this extract was for the estimation of phenols.
Procedure: $2 \mathrm{ml}$ of extract or standard was mixed with $1 \mathrm{ml}$ of Folin-Ciocalteu reagent (previously diluted with distilled water $1: 10 \mathrm{v} / \mathrm{v})$ and $1 \mathrm{ml}(7.5 \mathrm{~g} / \mathrm{l})$ of sodium carbonate. The mixture was vortexed for $15 \mathrm{~s}$ and allowed to stand for $15 \mathrm{~min}$ for colour development. The absorbance was measured at $765 \mathrm{~nm}$ using a spectrophotometer.

\section{Total flavonoid content estimation}

Principle: Determination of total flavonoids content was based on aluminium chloride method.

Preparation of standard: $10 \mathrm{mg}$ quercetin was dissolved in $10 \mathrm{ml}$ methanol, and various aliquots of 5$25 \mu \mathrm{g} / \mathrm{ml}$ were prepared in methanol.

Preparation of extract: $10 \mathrm{mg}$ of dried extracted dissolve in $10 \mathrm{ml}$ methanol and filter. Three $\mathrm{ml}$ $(1 \mathrm{mg} / \mathrm{ml})$ of this extract was for the estimation of flavonoid.

Procedure: $1 \mathrm{ml}$ of $2 \% \mathrm{AlCl}_{3}$ methanolic solution was added to $3 \mathrm{ml}$ of extract or standard and allowed to stand for $15 \mathrm{~min}$ at room temperature; absorbance was measured at $420 \mathrm{~nm}$.

\section{RESULTS AND DISCUSSION}

\section{Result of percentage yield of different extract}

Yield of Extraction: The crude extracts so obtained after the maceration process, each extracts were further concentrated on water bath evaporation the solvents completely to obtain the actual yield of extraction. To obtain the percentage yield of extraction is very important phenomenon in phytochemical extraction to evaluate the standard extraction efficiency for a particular plant, different parts of same plant or different solvents used. The yield of extracts obtained from different samples using different solvents are depicted in the table $1 \& 2$.

Table 1: Result of Percentage Yield of Extracts of Calotropis gigantea

\begin{tabular}{|c|l|c|}
\hline S. No. & \multicolumn{1}{|c|}{ Solvents } & Percentage Yield (\%) \\
\hline 1. & Chloroform extract & 3.8 \\
\hline 2. & Ethyl acetate extract & 3.9 \\
\hline 3. & Ethanol extract & 6.7 \\
\hline 4. & Aqueous extract & 5.9 \\
\hline
\end{tabular}

Table 2: Result of Percentage Yield of Extracts of Calotropis procera

\begin{tabular}{|c|l|c|}
\hline S. No. & \multicolumn{1}{|c|}{ Solvents } & Percentage Yield (\%) \\
\hline 1. & Chloroform extract & 3.4 \\
\hline 2. & Ethyl acetate extract & 3.6 \\
\hline 3. & Ethanol extract & 6.1 \\
\hline 4. & Aqueous extract & 4.8 \\
\hline
\end{tabular}

\section{Results of phytochemical Testing}

A small portion of the dried extracts were subjected to the phytochemical test using Kokate (1994) methods to test for alkaloids, glycosides, tannins, saponins, flavonoids and steroids separately for extracts of all samples. Small amount of each extract is suitably 
resuspended into the sterile distilled water to make the concentration of $1 \mathrm{mg}$ per $\mathrm{ml}$. The outcomes of the

Table 3: Result of Phytochemical Screening of Calotropis gigantea extracts

\begin{tabular}{|c|c|c|c|c|c|c|}
\hline S. No. & Constituents & $\mathbf{A}$ & B & $\mathbf{C}$ & D & Observation \\
\hline 1. & $\begin{array}{l}\text { Saponins } \\
\text { Froth Test } \\
\text { Foam Test } \\
\end{array}$ & $\begin{array}{l}\text {-ve } \\
\text {-ve }\end{array}$ & $\begin{array}{l}\text {-ve } \\
\text {-ve }\end{array}$ & $\begin{array}{l}+\mathrm{ve} \\
\text {-ve }\end{array}$ & $\begin{array}{l}\text { +ve } \\
+ \text { ve } \\
\end{array}$ & $\begin{array}{l}\text { Layer of foam } \\
\text { Layer of foam }\end{array}$ \\
\hline 2. & $\begin{array}{l}\text { Flavonoids } \\
\text { Alkaline Reagent Test } \\
\text { Lead acetate Test }\end{array}$ & $\begin{array}{l}\text {-ve } \\
\text {-ve }\end{array}$ & $\begin{array}{l}\text {-ve } \\
+\mathrm{ve}\end{array}$ & $\begin{array}{l}\text { +ve } \\
\text { +ve }\end{array}$ & $\begin{array}{l}\text { +ve } \\
\text {-ve }\end{array}$ & $\begin{array}{l}\text { Colourless } \\
\text { Yellow coloured ppt }\end{array}$ \\
\hline 3. & $\begin{array}{l}\text { Terpenoids } \\
\text { a) Salkowski test }\end{array}$ & -ve & -ve & $+\mathrm{ve}$ & $+\mathrm{ve}$ & Reddish brown coloured \\
\hline 4. & $\begin{array}{l}\text { Glycosides } \\
\text { a) Legal's Test: }\end{array}$ & -ve & +ve & $-\mathrm{ve}$ & -ve & Pink to blood red coloured \\
\hline 5. & $\begin{array}{l}\text { Alkaloids } \\
\text { a)Mayer's Test } \\
\text { b) Wagner's Test } \\
\text { c)Dragendroff's Test } \\
\text { d) Hager's Test }\end{array}$ & $\begin{array}{l}\text {-ve } \\
\text {-ve } \\
\text {-ve } \\
\text {-ve }\end{array}$ & $\begin{array}{l}\text {-ve } \\
\text {-ve } \\
\text {-ve } \\
\text {-ve }\end{array}$ & $\begin{array}{l}\text {-ve } \\
+ \text { ve } \\
\text {-ve } \\
+ \text { ve }\end{array}$ & $\begin{array}{l}\text {-ve } \\
\text {-ve } \\
+ \text { ve } \\
\text {-ve }\end{array}$ & $\begin{array}{l}\text { Yellow coloured but no ppt } \\
\text { Green coloured } \\
\text { Red coloured } \\
\text { Yellow coloured }\end{array}$ \\
\hline 6. & $\begin{array}{l}\text { Phenolics } \\
\text { a) Ferric Chloride Test: }\end{array}$ & -ve & $+\mathrm{ve}$ & $+\mathrm{ve}$ & $+\mathrm{ve}$ & Bluish black coloured \\
\hline 7. & $\begin{array}{l}\text { Carbohydrate } \\
\text { a)Molisch's Test } \\
\text { b) Benedict's Test } \\
\text { c) Fehling's Test }\end{array}$ & $\begin{array}{l}\text {-ve } \\
\text {-ve } \\
\text {-ve }\end{array}$ & $\begin{array}{l}\text {-ve } \\
\text {-ve } \\
\text {-ve }\end{array}$ & $\begin{array}{l}\text {-ve } \\
\text {-ve } \\
\text {-ve }\end{array}$ & $\begin{array}{l}\text {-ve } \\
\text {-ve } \\
\text {-ve }\end{array}$ & $\begin{array}{l}\text { Dark green Coloured } \\
\text { Orange red but ppt } \\
\text { Red ppt }\end{array}$ \\
\hline 8. & $\begin{array}{l}\text { Tannins } \\
\text { a) Gelatin Test: }\end{array}$ & -ve & -ve & $+\mathrm{ve}$ & -ve & White ppt \\
\hline
\end{tabular}

-ve =absent, +ve =present, $\mathrm{A}=$ Chloroform, $\mathrm{B}=$ Ethyl Acetate, $\mathrm{C}=$ Ethanol $\mathrm{D}=$ Water, $\mathrm{ppt}=$ precipitate

Table 4: Result of Phytochemical Screening of Calotropis procera extracts

\begin{tabular}{|c|c|c|c|c|c|c|}
\hline S. No. & Constituents & $\mathbf{A}$ & $\mathbf{B}$ & $\mathbf{C}$ & D & Observation \\
\hline 1. & $\begin{array}{l}\text { Saponins } \\
\text { Froth Test: } \\
\text { Foam Test: }\end{array}$ & $\begin{array}{l}+\mathrm{ve} \\
+\mathrm{ve}\end{array}$ & $\begin{array}{l}\text {-ve } \\
\text {-ve }\end{array}$ & $\begin{array}{l}\text { +ve } \\
\text {-ve }\end{array}$ & $\begin{array}{l}\text { +ve } \\
+ \text { ve }\end{array}$ & $\begin{array}{l}\text { Layer of foam } \\
\text { Layer of foam }\end{array}$ \\
\hline 2. & $\begin{array}{l}\text { Flavonoids } \\
\text { Alkaline Reagent Test } \\
\text { Lead acetate Test }\end{array}$ & $\begin{array}{l}\text {-ve } \\
\text {-ve }\end{array}$ & $\begin{array}{l}+ \text { ve } \\
\text {-ve }\end{array}$ & $\begin{array}{l}\text { +ve } \\
+ \text { +ve }\end{array}$ & $\begin{array}{l}+ \text { ve } \\
\text {-ve }\end{array}$ & $\begin{array}{l}\text { Colourless } \\
\text { Yellow coloured ppt }\end{array}$ \\
\hline 3. & $\begin{array}{l}\text { Terpenoids } \\
\text { a) Salkowski test }\end{array}$ & -ve & + ve & + ve & $+\mathrm{ve}$ & Reddish brown coloured \\
\hline 4. & $\begin{array}{l}\text { Glycosides } \\
\text { a) Legal's Test: }\end{array}$ & +ve & +ve & $+\mathrm{ve}$ & -ve & Pink to blood red coloured \\
\hline 5. & $\begin{array}{l}\text { Alkaloids } \\
\text { a)Mayer's Test: } \\
\text { b) Wagner's Test: } \\
\text { c)Dragendroff's Test: } \\
\text { d) Hager's Test: }\end{array}$ & $\begin{array}{l}\text {-ve } \\
\text {-ve } \\
\text {-ve } \\
\text {-ve }\end{array}$ & $\begin{array}{l}\text {-ve } \\
\text {-ve } \\
\text {-ve } \\
\text {-ve }\end{array}$ & $\begin{array}{l}\text {-ve } \\
+ \text { ve } \\
\text {-ve } \\
+ \text { ve }\end{array}$ & $\begin{array}{l}\text {-ve } \\
\text {-ve } \\
\text {-ve } \\
\text {-ve }\end{array}$ & $\begin{array}{l}\text { Yellow coloured but no ppt } \\
\text { Green coloured } \\
\text { Red coloured } \\
\text { Yellow coloured }\end{array}$ \\
\hline 6. & $\begin{array}{l}\text { Phenolics } \\
\text { a) Ferric Chloride Test: }\end{array}$ & +ve & -ve & $+\mathrm{ve}$ & +ve & Bluish black coloured \\
\hline 7. & $\begin{array}{l}\text { Carbohydrate } \\
\text { a)Molisch's Test: } \\
\text { b) Benedict's Test: } \\
\text { c) Fehling's Test: }\end{array}$ & $\begin{array}{l}\text {-ve } \\
\text {-ve } \\
\text {-ve }\end{array}$ & $\begin{array}{l}\text {-ve } \\
\text {-ve } \\
\text {-ve }\end{array}$ & $\begin{array}{l}\text {-ve } \\
\text {-ve } \\
\text {-ve }\end{array}$ & $\begin{array}{l}\text {-ve } \\
\text {-ve } \\
\text {-ve }\end{array}$ & $\begin{array}{l}\text { Dark green coloured } \\
\text { Orange red but ppt } \\
\text { Red ppt }\end{array}$ \\
\hline 8. & $\begin{array}{l}\text { Tannins } \\
\text { a) Gelatin Test: }\end{array}$ & -ve & -ve & $+\mathrm{ve}$ & +ve & White ppt \\
\hline
\end{tabular}

$\mathrm{A}=$ Chloroform, $\mathrm{B}=$ Ethyl Acetate, $\mathrm{C}=\mathrm{Ethanol} \mathrm{D}=$ Water, $\mathrm{ppt}=$ precipitate

From the results obtained it is clear that the Calotropis gigantea and Calotropis procera extracts plant shows the presence of Saponins, flavonoids, Carbohydrate,
Phenolics, Tannins were found present in roots when extracted with different solvents using maceration extraction procedure. The phytochemical analysis of 
Calotropis gigantea and Calotropis procera plant indicates the presence of phenols and flavonoids present in sufficiently enough quantity according to preliminary phytochemical analysis. Phenolic and Flavonoids are the phytochemicals that are present in ethanol extract.

Results of Estimation of Total Phenolic and flavanoid content estimation

Total Phenolic content estimation (TPC)

The content of total phenolic compounds (TPC) content was expressed as $\mathrm{mg} / 100 \mathrm{mg}$ of gallic acid equivalent of dry extract sample using the equation obtained from the calibration curve: $\mathbf{Y}=$ $\mathbf{0 . 0 4 2 X}+\mathbf{0 . 0 0 2}, \mathbf{R}^{2}=\mathbf{0 . 9 9 9}$, where $X$ is the gallic acid equivalent (GAE) and $\mathrm{Y}$ is the absorbance.

Calibration Curve of Gallic acid

Table 5: Preparation of calibration curve of Gallic acid

\begin{tabular}{|c|c|c|}
\hline S. No. & Concentration & Absorbance \\
\hline $\mathbf{0}$ & 0 & 0 \\
\hline $\mathbf{1}$ & 5 & 0.194 \\
\hline $\mathbf{2}$ & 10 & 0.422 \\
\hline $\mathbf{3}$ & 15 & 0.637 \\
\hline $\mathbf{4}$ & 20 & 0.848 \\
\hline $\mathbf{5}$ & 25 & 1.035 \\
\hline
\end{tabular}

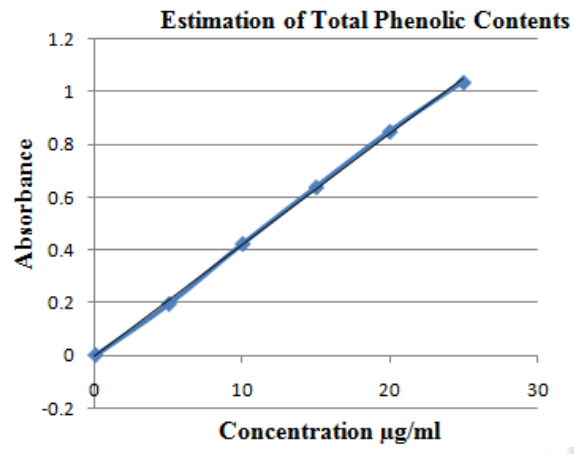

$y=0.042 x-0.002$ $R^{2}=0.999$

Table 7: Total Phenolic an

\begin{tabular}{|c|c|c|c|c|c|}
\hline S. No. & $\begin{array}{c}\text { Estimation of bioactive } \\
\text { compounds }\end{array}$ & Chloroform & Ethyl acetate & Ethanol & Water \\
\hline 1. & $\begin{array}{c}\text { Total Phenol (GAE) } \\
(\mathrm{mg} / 100 \mathrm{mg})\end{array}$ & - & 0.292 & 2.128 & 1.245 \\
\hline 2. & $\begin{array}{c}\text { Total flavanoid (QE) } \\
(\mathrm{mg} / 100 \mathrm{mg})\end{array}$ & 0.283 & 0.515 & 1.516 & 0.670 \\
\hline
\end{tabular}

Table 8: Total Phenolic and Total flavanoid content of extracts of Calotropis procera

\begin{tabular}{|c|c|c|c|c|c|}
\hline S. No. & $\begin{array}{c}\text { Estimation of bioactive } \\
\text { compounds }\end{array}$ & Chloroform & Ethyl acetate & Ethanol & Water \\
\hline 1. & $\begin{array}{c}\text { Total Phenol (GAE) } \\
(\mathrm{mg} / 100 \mathrm{mg})\end{array}$ & 0.500 & - & 1.866 & 1.023 \\
\hline 2. & $\begin{array}{c}\text { Total flavanoid (QE) } \\
(\mathrm{mg} / 100 \mathrm{mg})\end{array}$ & - & 0.503 & 1.271 & 0.593 \\
\hline
\end{tabular}




\section{CONCLUSION}

The results have shown that the main components i.e., flavonoids, alkaloids, tannins and phenolic compounds were present in ethanolic extract of of C. Gigantea and C.Procera roots. The content of total phenols and Flavonoids in different extracts, expressed as gallic acid equivalents (GA) per milligram of dry extract, the highest phenolic and Flavonoids content was found in ethanol extracts of Calotropis gigantean and Calotropis Procera.

\section{REFERENCES}

1. Ahmed M, Rana AC, Dixit VK, Calotropis species (Ascelpediaceae): A comprehensive review, Pharmacognosy Magazine, 2005; 2:48-52.

2. Kumar A. Calotropis procera, a plant of traditional medicine in India. Humboldt Fellow and Science; 2009. P.1-2.

3. Mukherjee PK. Quality Control of Herbal Drugs. 2nd Edition. Business Horizons; 2007. P. 2-14.

4. Tatiya A, Surana S, Bhavsar S, Patil D, Patil Y, Pharmacognostic and preliminary phytochemical investigation of Eulophia herbacea Lindl. Tubers (Orchidaceae), Asian Pac J Trop Disease, 2012; 2(Suppl 1):S50-55.

5. Kokate CK, Purohit AP, Gokhale SB. Pharmacognosy. 1st Edition, Nirali Prakasan, Pune, 1990, p.123.

6. Khandelwal KR. Practical Pharmacognosy Technique and Experiments, $23^{\text {rd }}$ Edn,, Nirali Prakashan; 2005.P. 15, 29, 149,56 ,

7. Kokate, CK.Practical Pharmacognosy, $4^{\text {th }}$ Edn., Vallabh Prakashan; 1994. P.112,120,
In view of all the medicinal importance associated with the phytocompounds found in these plant species, further investigation should be carried out in order to isolate, identify, characterize and elucidate the structures of these bioactive principles and enhance their potentials for industrial and pharmaceutical utilization. Further investigation should be carried out on the diversity of chemical constituents, level of toxicity and the physiology of these plants.

8. Obasi NL, Egbuonu ACC, Ukoha PO, Ejikeme PM, Comparative phytochemical and antimicrobial screening of some solvent extracts of Samanea saman pods, African journal of pure and applied chemistry, 2010; 4(9):206-212.

9. Audu SA, Mohammed I, Kaita HA, Phytochemical screening of the leaves of Lophira lanceolata (Ochanaceae), Life Science Journal, 2007; 4(4):75- 79.

10. Olajuyigbe $\mathrm{O}$, Anthony J, Phenolic Content and antioxidant property of the bark extract of Ziziphus mucronata wild. Subsp. Mucronata wild, BMC, Complementary and alternative medicine, 2011; 11:130.

11. Quality Control Methods for Medicinal Plant Materials. World Health Organization, Geneva. AITRS Publisher \& Distributors, New Delhi. 2002; 14-17; 33-36:51-52.

12. Basset J, Denny J, Jeffery JH and Mendham J. Vogel's Text Book of Quantitative Inorganic Analysis, 4th Edition, ELBS - Longman, Essex, UK, 1985, p.196.

13. Harbourne JB, Phytochemical methods - A guide to Modern Techniques of Plant Analysis. 2nd Edition, Chapman and Hall, London, 1984, p.4-120. 